\title{
CULTURE AND FOOD SECURITY OF THE MOWEWE COMMUNITY DURING THE COVID-19 PANDEMIC
}

\author{
La Ode Topo Jers ${ }^{\left(1^{*}\right)}$, Erens Elvianus Koodoh (2), Hasniah ${ }^{(3)}$, Abdul Jalil (4) \\ 'La Ode Muhammad Ruspan Takasi ${ }^{(5)}$; Alias $\left({ }^{6}\right)$, I Kadek Sindu (7) \\ 123467 Faculty of Cultural Science, Universitas Halu Oleo, Kendari, Indonesia. \\ 5 Faculty of Teacher Training and Education, Universitas Terbuka, Kendari, Indonesia.
}

\section{ARTICLE INFORMATION

$\begin{array}{ll}\text { Submitted } & : 31^{\text {st }} \text { August } 2021 \\ \text { Review } & : 01^{\text {st }} \text { October } 2021 \\ \text { Accepted } & : 06^{\text {th }} \text { December } 2021 \\ \text { Published } & : 18^{\text {th }} \text { December } 2021 \\ \text { Available Online }: \text { December } 2021 .\end{array}$

\section{KEYWORDS}

Culture; food security; ecology; cooperation; local

\section{CORRESPONDENCE}

*E-mail: laode.topojers@uho.ac.id

\begin{abstract}
A B S T R A C T
Food is a critical aspect of community resilience. The Covid-19 pandemic however, has affected the natural environment, making food supply scarce and ultimately impacting economic and national stability. Despite this, the Mowewe community shares a local culture by which its people get empowered to maintain food security. Therefore, this study aims to discover and describe the local community's culture in Mowewe District in establishing a food security system. The method used was ethnography with a qualitative approach. Data were collected through participant observation, in-depth interviews, and documentation, after which the data were analyzed using qualitative descriptive techniques. The findings revealed that the local culture of the Mowewe community was built upon the concept of Mekambare, principles of gotong royong (cooperation), and ecological adaptation. The Mowewe community was of deep concern for the pattern of life balance during the pandemic. They took advantage of natural resources by clearing agricultural land to grow rice, corn, patchouli, and sago and keeping bees in the forest to produce honey for an additional source of income and immunity.
\end{abstract}

\section{A. INTRODUCTION}

$\mathrm{T}$ his study highlights the implementation of the local food-based culture of the Mowewe community during the COVID-19 pandemic. The culture is rooted in the community's habits and traditions in interacting with their natural environment, with which they respond to various social changes, including when the pandemic stroke. It takes the form of voluntary land cultivation and harvest-sharing habits. In addition, it is manifested through the community's use of the home yard as a productive family garden to produce foodstuff. Not only do they consume the foodstuff for themselves but also give it to other people in need. With the practice of culture as such, the Mowewe community can manage their food security, and therefore survive the crisis. Food security management for a community is essential in dealing with continuously changing life. This is because food security is directly proportional to the level of welfare and prosperity of a country $^{1}$ (Wattimena, 2021).

Culture includes things humans acquire and learn as social and individual beings ${ }^{2}$ (Soekanto, 2017:148). Human interaction with their environment indirectly allows them to understand their environment better. Such aspects as population,

\footnotetext{
${ }^{1}$ Wattimena, J. A. Y., \& Hattu, V. V. (2021).Ketahanan Pangan Masyarakat Adat Sebagai Wujud Pemenuhan Ham Dalam Masa Pandemi Covid-19. SASI, 27(2), 247-266.

2 Soekanto, Soerjono. 2017. Sosiologi Suatu Pengantar. Jakarta: Rajawali Pers. Hal 148
} 
public health, technology, natural resources, and systems of community social organization interact and influence one another, providing opportunities for balance and food security. Local community knowledge about their food can overcome food security issue ${ }^{3}$ (Puspita, 2017). Home yards can be utilized in developing a food estate to strengthen the food security system ${ }^{4}$ (Wulandari, 2020). Kastanja (2019) argued that yards utilization could meet the community's food availability ${ }^{5}$.

For local communities, culture is a process of adjustment or adaptation. Maintaining life can be seen as a cultural expression in a community group with its environment. The cultural behavior containing the local wisdom of the community is believed to have specific values that favor natural ecosystems and environment preservation. Ohleky (2018) states that such local wisdom can support food security sustainability ${ }^{6}$. Furthermore, Kusmiyati (2021) put forward that local food during pandemic outbreaks needs to be utilized as much as possible to support community food security ${ }^{7}$. The Mowewe people, for instance, make their home yard a place to grow various food crops to keep food stabilized. In addition, Sihimbong (2021) said that efforts to diversify local food could be made sustainably, especially in utilizing local food sources as the basis for food security ${ }^{8}$. Furthermore, Y.P (2008) stated that food diversification based on potential locals could enhance food security and break the chain of dependence on rice ${ }^{9}$. Local food-based

\footnotetext{
3 Puspita, D., Fuka, D. E., \& Notosoedarmo, S. (2017). Pengetahuan Lokal Masyarakat Timor dalam Upaya Menjaga Ketahanan Pangan Melalui Pangan Lokal. Cakrawala Jurnal Penelitian Sosial, 6(1), 75-92

${ }^{4}$ Wulandani, B. R. D., \& Anggraini, W. (2020). FOOD ESTATE SEBAGAI KETAHANAN PANGAN DI TENGAH PANDEMI COVID-19 DI DESA WANASABA. SELAPARANG Jurnal Pengabdian Masyarakat Berkemajuan, 4(1), 386-390.

${ }^{5}$ Kastanja, A. Y., Patty, Z., Dilago, Z., \& Namotemo, U. H. (2019). Pemanfaatan Pekarangan Untuk Mendukung Ketahanan Pangan Masyarakat Desa Kali Upa. Jurnal Pengabdian Masyarakat, 1(1), 173-181.

${ }^{6}$ Ohleky, M. P., Pattiselanno, A. E., \& Kaplale, R. (2018). Namlai Kerne: Kearifan Lokal Dan Ketahanan Pangan Masyarakat Desa Werwaru Kecamatan Moa Kabupaten Maluku Barat Daya. Agrilan: Jurnal Agribisnis Kepulauan, 5(2), 114-131.

7 Kusmiyati, K., Rasmi, D. A. C., Sedijani, P., \& Bachtiar, I. (2021).Penyuluhan Tentang Pemanfaatan Pangan Lokal untuk Menunjang Ketahanan Pangan di Masa Pandemi Covid 19. Jurnal Pengabdian Magister Pendidikan IPA, 4(4).

8 Sihombing, Y. (2021). Diversifikasi pangan lokal untuk mendukung ketahanan pangan pada masa pandemi covid19. Buletin teknologi dan informasi pertanian, 19(1), 1.

9 YP, N. M. S. (2008). Diversifikasi Konsumsi Pangan Pokok Berbasis Potensi Lokal dalam Mewujudkan Ketahanan Pangan 249 | P a g e

https://doi.org/10.25077/jantro.v23.n2.p248-255.2021
}

diversification can establish a food security system in the community ${ }^{10}$ (Satmalawati, 2016).

While we have seen the increasingly modern and global era, the world was suddenly shocked by the Coronavirus outbreak. This pandemic then began to affect various sectors of social life. The restrictions to social activities to indirectly prevent the spread of SARS-CoV-2 have caused many people to lose their jobs and limited food supplies, especially their daily needs. The spread of Covid-19 has not only impacted urban communities but also has reached remote rural areas, and Mowewe District is no exception. As a result, the Mowewe community began to be haunted by the deadly Covid-19. Their mobility from day to day was limited by the emergence of various restrictions imposed by the government to prevent and control Covid-19, leading to the gradual decline of food supplies and economic hardship. The economic difficulties due to this epidemic have forced the Mowewe people to depend on natural resources in their environment. Their dependence on the natural environment represents a cultural behavior passed down from generation to generation.

This cultural behavior is grounded in the principles of cooperation, known as cooperative attitude, which helps them rise. Hanif (2021) argues that in the culture of the Madiun community, the mitigation step in dealing with the Covid-19 outbreak is by applying a cooperative attitude and leveraging food barns as a strategy for providing food during disasters as well as anticipatory steps when food shortages occur ${ }^{11}$. Moran (2000:85-86) states that the interaction between humans living in an area takes the forms of cooperation, mutualism, commensalism, and amensalism. Through these, humans provide well-being to one another and allow food sources such as water and food to exist. The importance of maintaining the relationship between the community and the natural environment makes agricultural land a source that can generate economic production ${ }^{12}$. Meanwhile, to meet food

Rumahtangga Pedesaan di Kecamatan Semin Kabupaten Gunung Kidul. Economic Journal of Emerging Markets, 13(1).

10 Satmalawati, M. E. M., \& Falo, M. (2016). Diversifikasi Konsumsi Pangan Pokok Berbasis Potensi Lokal Dalam Mewujudkan Ketahanan Pangan Di Kecamatan Insana Barat Kabupaten Timor Tengah Utara NTT. Prosiding Semnas Hasil Penelitian.

11 Hanif, M. (2021). Kearifan Lokal Masyarakat Kabupaten Madiun Dalam Menyikapi Pandemi Covid-19. Jurnal Antropologi: Isu-Isu Sosial Budaya, 23(1), 27-36.

12 Moran, F. Emilio. 2000. Human Adaptability An Introduction to Ecological Anthropology. Boulder. Corad. Westview Press Inc. A Member of the Perseus Books Group. 
demand, processing forest products such as hunting forest honey, farming activities, and planting rice become a priority. In a micro-ethnographic study of the jungle people, John (2021) found that the behavior in dealing with the COVID-19 outbreak was carried out through a combination of activities such as hunting and gathering as access to fulfill food availability while strengthening food security ${ }^{13}$. The adaptation process carried out by the Mowewe community is a survival strategy.

People live in a cultural system that allows them to manage various natural resources in their environment properly and wisely. Rianse (2019) argues that preserving nature is part of maintaining food crop production to remain sustainable ${ }^{14}$. Cultural behavior shows the adaptability of society in dealing with every social issue, including dealing with the Coronavirus outbreak through the improved immune system. Rahmanindar et al. (2021:307) hold that the higher the number of positive corona cases in Indonesia, the higher a person's stamina is necessary ${ }^{15}$. For this reason, efforts to increase body immunity are needed, for instance, by utilizing food sources such as honey. The ability to provide food sources for family members has grown and formed social resilience. The way the people in Mowewe apply their knowledge and actions makes them continue to thrive amidst crisis. Applying local wisdom as a cultural basis in managing natural resources and the environment preserves natural ecosystems and land fertility. There is a belief in the Mowewe community regarding the existence of Sanggoleo Mbae (rice goddess), who maintains the fertility of agricultural land. The conception of Sanggoleo Mbae aligns with Azhima's (2020) view, which suggests that the concept of Déwi Sri originating from rice contains cultural values that impact environmental sustainability and community food security ${ }^{16}$.

\footnotetext{
13 John, K., Prasetijo, A., \& Sutiningsih, D. (2021). Ketahanan Pangan Keluarga Orang Rimba Selatan Taman Nasional Bukit Dua Belas Jambi: Studi Mikroetnografi Keluarga Njalo Dalam Menghadapi Pandemik. Jurnal Antropologi: Isu-Isu Sosial Budaya, 23(1), 83-92.

${ }^{14}$ Rianse, U., Iswandi, R. M., Arafah, N., \& Hamzah, A. (2019). Pengetahuan Lokal Masyarakat Pulau Binongko dalam Sistim Ketahanan Pangan. Buletin Penelitian Sosial Ekonomi Pertanian Fakultas Pertanian Universitas Haluoleo, 21(1), 36-44.

${ }^{15}$ Rahmanindar, N., Zulfiana, E., \& Harnawati, R. A. (2021). Penerapan Hidup Sehat dengan Mengkonsumsi Madu dan Vitamin untuk Meningkatkan Imunitas Petugas Kesehatan serta Mencegah Covid-19 Di RSUD Kardinah Kota Tegal. Jurnal ABDINUS: Jurnal Pengabdian Nusantara, 4(2), 306-310.
}

${ }^{16}$ Azhima, F. F., Priyatna, A., \& Muhtadin, T. (2020). Mitos dan representasi Dewi Sri dalam ritual sinoman upacara adat Mapag
The food security system embedded in the habits of rural communities needs serious attention to be able to make a total contribution to human survival in general. Pramudita (2020) argues that the availability of food barns during the COVID-19 pandemic has a vital role in maintaining human survival ${ }^{17}$. In other words, it is crucial to build community food security, especially to face the severe impact of the current Covid-19 pandemic. Therefore, an in-depth study of the local community's culture in the District of Mowewe in building a food security system needs to be conducted. The purpose of this study is to describe the local community's culture in building a food security system during the Covid-19 pandemic in Mowewe District, East Kolaka Regency, as part of the community's survival strategy during the pandemic.

\section{B. METHOD}

$\mathrm{T}$ his study was conducted in Mowewe District, East Kolaka Regency, South East Sulawesi Province. The Mowewe district is situated at the foot of Mount Mowewe, and it has a population of 9202. The main livelihoods of the population are farmers, cultivating the rice field or farm alongside the foot of Mount Mowewe. Many also work as beekeepers, and a few work in government agencies as civil servants.

This study employed an ethnographic and qualitative approach to reveal the local community's culture that formed food security during the COVID19 pandemic in the District of Mowewe, East Kolaka Regency. Spradley (2006:ix) states that an ethnographic study is a holistic-integrative study, a thick description, and a qualitative analysis to get the main points as a whole ${ }^{18}$. The informants in this study included the head of the village, village secretary, custom leader, religious leaders, and six leaders of the Mowewe community. The data collection technique used was open and in-depth observation and interviews. The observation model in the study was carried out by directly observing the activities of the Mowewe community in building a

Sri di Desa Slangit Kabupaten Cirebon: Kajian Semiotika. Metahumaniora, 10(2), 217-229.

17 Pramudita, M., Anggraini, D. D., Hidayat, N., Yuniardiningsih, E., Apriliyanti, M. D., Wangi, P., \& Ma'rufi, I. (2020).Lumbung Pangan Sebagai Upaya Ketangguhan Pangan Masa Pandemi Covid-19 Desa Kabuaran Bondowoso. Multidisciplinary Journal, 3(1), 34-40.

${ }^{18}$ Spradley, James P. 2006. Metode Etnografi. Yogyakarta: PT Tiara Wacana. 
food security system and by recording important related events. In collecting data, open and in-depth interviews were carried out with structured and unstructured interviews. The data collected were analyzed using a qualitative descriptive technique. Data analysis was carried out by reviewing all available data from various sources, including observations, interviews, and documentation. Data reduction was conducted using an abstraction model once the data review was done.

\section{RESULT AND DISCUSSIONS}

T he people of Mowewe pass on cultural knowledge to every generation. This cultural knowledge is transformed into various forms of local wisdom and is leveraged to survive in every situation. During the Covid-19 pandemic, people's mobility was affected, especially regarding access to outside, making it difficult for economic activities to develop. These conditions made the Mowewe people rely on natural resources in the surrounding environment to continue to survive. The survivability as such arose from the shared habits or cultures in daily life, such as farming or gardening. People's livelihoods, mainly in the agricultural and plantation sectors, provided new hope for adaptation to life during the COVID-19 pandemic. In addition, the Mowewe people had a habit of processing forest products into consumable food for daily life, such as being honey hunters or honey farmers. They even become corn and patchouli farmers, even as cultivators in the fields. Knowledge of the management and utilization of forest and garden products is a pillar of the Mowewe community's food security. Through cultural knowledge that has become a hereditary tradition, collective social awareness about the importance of preserving nature and adapting to the environment is created naturally.

Mowewe residents have long coexisted with their natural resources. The cultural practices show that nature is a source of life and an adaptation arena. The food security system in the daily life of the Mowewe people in principle has been formed for a long time. That is why when the coronavirus outbreak struck; it did not cause a more severe social shock. Although community members felt the socioeconomic impacts, food could still be adequately available since they processed forest products into foodstuff or household food reserves.

\section{The Form of the Mowewe Community's Food Security System}

In the culture of the Mowewe people, there is a habit of cooperation or known as the Mekambare culture. Togetherness in Mekambare culture can be manifested in various forms of social activities. The forest products have long been utilized, traded, or used for family food reserves as a survival system in the socio-cultural environment of the community. As stated by one resident of Mowewe District as follows:

\begin{abstract}
"Mowewe people are used to finding and processing forest products. They usually go into the forest to look for forest honey. Some are working on land around the forest to farm corn and patchouli. People in Mowewe also have a staple food other than rice, namely sago. This area has long grown sago. People use traditional techniques to process food sources that are consumed daily. So honey, corn, rice, sago are our food sources here. Patchouli harvest can be sold to collectors for processing. In addition, we can also use the yard of the house to grow various types of vegetables so that we can consume it ourselves as a family." (Interview August 21, 2021).
\end{abstract}

The culture of the community in adapting to its environment has become a cornerstone of the local economy. Since a long time ago, the Mowewe people have been accustomed to processing forest products as an alternative to meet their daily needs and also as a source of livelihood. The culture of farming and gardening in this community is gradually becoming a food security system that helps the community to survive the difficult situation of the Covid-19 pandemic. This system is established by processing sago, honey, corn, and rice and making the home yard an area for growing food crops.

\section{a. Utilization of Sago}

Sago is the quintessential food of the Mowewe people. Since ancient times, the territory of the Mekongga Kingdom, located on the peninsula of the Kolaka region, has recognized sago as a plant that is easy to grow and is one of the food crops to substitute rice. The use of sago as a foodstuff by the Mowewe people is a strategic step to complement food sources for household consumption. It can be understood that the promotion of sago tree planting is due to the enormous benefits it has as a 
community food raw material. For the Mowewe people, especially the Tolaki people, sago is a food source other than rice. This is expressed by the informant in the following interview:

"The sago trees growing in Mowewe District are quite abundant and fertile. The sago palms grow on the river banks. People usually plant sago in the river basin area so that at harvest time, the allocation is not far from the water source to clean the sago. Mowewe people use sago as an alternative to rice, it is also made as a traditional cake. In essence, it is not difficult to process sago into food. Especially if it becomes sago flour (known as tawaro), it can last for a long period of time. So, at harvest time, the sago can be used as a daily staple food for the family or alternatively it can also be sold." (Interview August 21, 2021).

As a staple food, growing sago palm has been practiced for a long time by the community. They even filled their garden with sago. This condition illustrates that sago is an important food for the Mowewe community. In the customs of the Tolaki people, sago has the added value mainly as a family foodstuff and as a product that can be marketed so that it has economic value. According to the Mowewe community, the clues to identify the characteristics of a sago tree ready to be harvested are when the leaf midrib looks shorter, and flower buds begin to appear. It can also be checked by making a hole in the sago stem as deep as one meter and then taking the pith to chew and squeeze. If it turns out that the fruit's juice is cloudy, it means that the sago tree is ready to be harvested. That's how the Mowewe people know sago as a raw material for food in their daily life. Furthermore, in the belief of the Tolaki community in Mowewe District, sago has a spirit called Sanggoleo Ndawaro, and its presence makes sago have a religious element that guides the actions and attitudes of the community to preserve the sago tree continuously. Such belief forms a paradigm in people's minds to make the best use of sago.

\section{b. Utilization of Corn}

The development of the community food security system is a priority. In establishing a food security system, the Mowewe community also utilize corn as a source of family food security. In the community farming system, corn is also developed. Knowledge of corn as a food commodity is a survival option during the Corona outbreak. Corn has a relatively long harvest period, so the people of Mowewe tend to sell their corn plantations, then the money earned is used for other needs to support daily life. However, it is also often consumed at every harvest, some are finished, but most of it was processed to be marketed as animal feed. As stated by the informant in the following interview that:

"Many people in Mowewe have
been growing corn. Corn harvest is
usually used for feeding
community's cattle. However,
some of them are used as food for
family members. Young corn is
used as a complement of
vegetables, while old corn is widely
used as animal feed." (Interview,
August 22, 2021).

From an economic point of view, the maize agricultural products of the Mowewe community tend to be used as animal feed ingredients, and a small portion is used for family consumption. From corn plantation, the community can earn additional income to buy basic needs for family members such as clothing, food, and shelter. The sale of corn as a feed ingredient is seen as very helpful for the community compared to young corn so that the people of Mowewe are more likely to produce old corn than young corn. On the other hand, old corn is also used as animal feed.

\section{c. Utilization of Pachouli}

During the COVID-19 pandemic, many farmers in Mowewe District began to switch their activities to patchouli farming. Since patchouli prices improved, patchouli farmers in Mowewe began to work on their farms again to develop a patchouli farming system. Mowewe people, especially in Ulumowewe Village, started planting patchouli because it was cheaper than the other plants. Moreover, patchouli is a shortterm crop. Mowewe community farming activities during the pandemic opened a farming area used as patchouli planting to support the family's economic needs. As stated by one of the following informants:

"Indeed, culturally, we have been familiar with the culture of cooperation in Ulumowewe Village. Many people in the Mowewe district cultivate patchouli. Now patchouli has a good price, so during this pandemic, we don't go out much, just farm, grow patchouli instead. We traditionally refine its oil for sale and we used the money 
to buy household necessities, particularly food". (Interview on August 22, 2021)

The utilization of vacant land in Mowewe District was a positive activity as it made the community active in the agricultural sector. The community showed this by preparing a food security system for their family members. The farmers filled their farms with patchouli plants to improve the family's economy. This culture was undoubtedly a strength in the face of the coronavirus outbreak. In the Mekambare concept, the community collectively works together to develop patchouli plants as a source of livelihood. As the pandemic hit them, the culture of Mekambare provided an opportunity for the community to strengthen each other. Besides, it raised awareness among the community members to form cooperation.

\section{d. Utilization of Honey}

Referring to the increasing number of cases of the COVID-19 disease in Indonesia, each individual must increase their body immunity. Much evidence has pointed to the benefits of honey to increase stamina. Health workers, for instance, maintain their stamina or immunity by consuming honey as a natural antibiotic. Socioculturally, Mowewe people, have long known about the benefits of honey for health.

The richness of Mowewe forest products makes the flora and fauna ecosystem that lives in it continue to provide resources for the community. Realizing honey's many functions and benefits, many people work as honey seekers in the forest. The knowledge of the surrounding community about honey and bees is closely related to the forest, so they are cautious in maintaining and preserving the forest ecosystem so that it remains sustainable. As stated by the following informant:

"People in Mowewe Regency get a lot of honey in the forest. We thank God, the produce is plentiful and the forest is still awake. This forest is also a source of our life apart from rice fields. Many of our people here work as honey seekers in the forest, even it can take days when going into the forest to look for honey, before returning to the village. Usually they do it in groups. Some are on duty as climbers because the honey is in the tree, some are on guard below when the honey is being lowered and some are taking it. Don't be surprised if there are lots of honey sellers along the road in
Kolaka who line up at every crossroads." (Interview, on August 21, 2021)

This activity illustrates that the Mowewe people make honey as a complementary source of food needs. Sustainable forests and honey are believed to have a causal relationship. This makes us assume that the state of the forest can affect the presence of honey-producing bees. The tradition to utilize honey as a drink to boost their immunity by Mowewe people dates back to ancient times. Thus, when the Corona Virus was spreading, the Mowewe people, in principle, already had honey reserves as a health supplement. In another interview. It was found that in preserving the forest ecosystem, these honey seekers no longer use the smoking method to repel honey bees. Instead, they use self-protection against bees smeared all over their bodies. For them, this brings two advantages; honey-producing bees do not die; honeycomb branches or twigs are not damaged by fire or smoke. In addition, there is no need to break branches or tree trunks as a smoking medium. During the COVID-19 pandemic, forest products in the form of honey were used as a source of livelihood and a complementary source of community food to maintain health and increase endurance.

\section{Ideology of Sanggoleo Mbae (Goddess of Rice)}

Mowewe is famous for its soil fertility. The flat land that stretches along the village is widely used as rice fields by the community. Many local people work as cultivators in the fields to feed their families. Rice is the primary source of food security for the community. Based on BPS data (2020:81), the area of land used by the community to clear rice fields reaches 1,212 hectares or about $7.80 \%$ of the total area of Mowewe District. The community's high interest in cultivating rice fields cannot be separated from the belief that there is a spirit of Sanggoleo Mbae who always takes care of the existing rice. As stated by the following informant:

"We, this community, have a belief regarding this rice. So here we believe that rice has a spirit called Sanggoleo Mbae or the rice goddess. We believe that as long as we can cultivate the fields well, then Sanggoleo Mbae will help us by providing soil fertility and abundant harvests. In this field, we have two models; first, there is the owner of the field; second, there are also cultivators of the fields. These cultivators usually do not own rice fields, so they work for the owners of the 
fields with a profit-sharing system or at harvest these cultivators will be given rice instead for their family's food reserves. But some rice field owners cultivate their rice fields on their own by cooperating." (Interview on August 21, 2021)

Their belief in Sanggoleo Mbae indirectly fosters their self-confidence while farming. Their hopes for rice remain as Sanggoleo Mbae (the goddess of rice) is still with them, although the crisis is striking. Rice from farming activities will be kept for food reserves for several months, even until the next harvest season. The reserves can last up to four through five months. This way, the Mowewe people build their food security system. The community believes that arbitrary exploitation of nature and the environment, especially in cultivating rice fields, can anger the spirit of Sanggoleo Mbae. Thus, farmers or rice cultivators must appreciate her existence by consistently doing good things for the environment and fellow citizens.

\section{Functions of Local Culture as a Food Security System}

In a social context, humans become cultural creators and actors at the same time who guide life in community groups. Humans can create a culture, human, and technology of superiority with their ability and knowledge. Local culture in the Mowewe community is an essential element in building a food security system. The culture of Mekambare provides opportunities for community members to help other residents' difficulties by giving assistance in the form of thoughts and materials. This can be seen when the farm harvest begins. Usually, some parts of the harvest are shared with neighbors as an expression of gratitude. This practice of culture is aimed at resilience and survival. This study contributes to the development of socio-cultural anthropology, especially in developing insights into local food for the community.

\section{CONCLUSIONS}

$\mathrm{T}$ he values of togetherness, simplicity, obedience and conservation as guidelines appear in the local culture of the Mowewe community in Mowewe District. These four components are pillars of the food security development of the Mowewe community in the face of the Covid-19 pandemic. In local culture, the community has the concept of Mekambare as the principle of cooperation that evokes a sense of concern for the environment with community members. This cooperation activity is demonstrated in daily life by assisting other community members in trouble and difficulty. Examples of such behavior are farming and planting rice in the fields, planting corn, patchouli, and distributing the harvest when the harvest season arrives. In the Mowewe tradition, food needs are obtained by processing rice, rice, sago, corn, honey, and vegetables into food ingredients. In addition, belief in supernatural beings such as the spirit of Sanggoleo Mbae (the goddess of rice) or Sanggoleo Ndawaro in sago plants makes people more conservative towards nature and the environment. They believed that their arbitrary and destructive acts could anger the spirits and affect the plants. Of course, the destruction of plants will disrupt the food security system of the community. Therefore, the locals always respect and appreciate the entire forest ecosystem by protecting and preserving it.

\section{E. ACKNOWLEDGEMENT}

W e are grateful to the Rector of Halu Oleo University for his support to write this article. We would like to thank the Mowewe District government and community leaders for their cooperation during this research.

\section{REFERENCES}

Azhima, F. F., Priyatna, A., \& Muhtadin, T. (2020). Mitos dan representasi Dewi Sri dalam ritual sinoman upacara adat Mapag Sri di Desa Slangit Kabupaten Cirebon: Kajian semiotika. Metahumaniora, 10(2), 217-229. https://doi.org/10.24198/metahumaniora.v10i2.25733

Badan Pusat Statistik Kabupaten Kolaka Timur. (2020). Kecamatan Mowewe Dalam Angka, Mowewe Subdistrict In Figures 2020. Kolaka Timur. BPS Kolaka Timur. https://koltimkab.bps.go.id/publication/2021/02/26/8d19a9c06e986b5e17a53d50/kabupaten-kolakatimur-dalam-angka-2021.html 
Hanif, M. (2021). Kearifan lokal masyarakat Kabupaten Madiun dalam menyikapi pandemi covid-19. Jurnal Antropologi: Isu-Isu Sosial Budaya, 23(1), 27-36. https://doi.org/10.25077/jantro.v23.n1.p27-36.2021

Herimanto \& Winarno. (2015). Ilmu Sosial dan Budaya Dasar.Jakarta: Bumi Aksara.

John, K., Prasetijo, A., \& Sutiningsih, D. (2021). Ketahanan pangan keluarga Orang Rimba Selatan Taman Nasional Bukit Dua Belas Jambi: Studi mikroetnografi keluarga njalo dalam menghadapi pandemik. Jurnal Antropologi: Isu-Isu Sosial Budaya, 23(1), 83-92. https://doi.org/10.25077/iantro.v23.n1.p83-92.2021

Kastanja, A. Y., Patty, Z., Dilago, Z., \& Namotemo, U. H. (2019). Pemanfaatan pekarangan untuk mendukung ketahanan pangan Masyarakat Desa Kali Upa. Jurnal Pengabdian Masyarakat, 1(1), 173-181.

Kusmiyati, K., Rasmi, D. A. C., Sedijani, P., \& Bachtiar, I. (2021). Penyuluhan tentang pemanfaatan pangan lokal untuk menunjang ketahanan pangan di masa pandemi covid 19. Jurnal Pengabdian Magister Pendidikan IPA, 4(4).

Moran, F. E. (2000). Human Adaptability An Introduction to Ecological Anthropology. Boulder. Corad. Westview Press Inc. , A Member of the Perseus Books Group.

Ohleky, M. P., Pattiselanno, A. E., \& Kaplale, R. (2018). Namlai kerne: Kearifan lokal dan ketahanan pangan masyarakat Desa Werwaru Kecamatan Moa Kabupaten Maluku Barat Daya. Agrilan: Jurnal Agribisnis Kepulauan, 5(2), 114-131. http://dx.doi.org/10.30598/agrilan.v5i2.159

Puspita, D., Fuka, D. E., \& Notosoedarmo, S. (2017). Pengetahuan lokal masyarakat Timor dalam upaya menjaga ketahanan pangan melalui pangan lokal. Cakrawala Jurnal Penelitian Sosial, 6(1), 75-92. Retrieved from https://ejournal.uksw.edu/cakrawala/article/view/1288

Pramudita, M., Anggraini, D. D., Hidayat, N., Yuniardiningsih, E., Apriliyanti, M. D., Wangi, P., \& Ma'rufi, I. (2020). Lumbung pangan sebagai upaya ketangguhan pangan masa pandemi covid-19 Desa Kabuaran Bondowoso. Multidisciplinary Journal, 3(1), 34-40. https://doi.org/10.19184/multijournal.v3i1.23685

Rahmanindar, N., Zulfiana, E., \& Harnawati, R. A. (2021). Penerapan hidup sehat dengan mengkonsumsi madu dan vitamin untuk meningkatkan imunitas petugas kesehatan serta mencegah covid-19 di RSUD Kardinah Kota Tegal. Jurnal ABDINUS: Jurnal Pengabdian Nusantara, 4(2), 306-310. https://doi.org/10.29407/ja.v4i2.14705

Rianse, U., Iswandi, R. M., Arafah, N., \& Hamzah, A. (2019). Pengetahuan lokal masyarakat Pulau Binongko dalam sistim ketahanan pangan. Buletin Penelitian Sosial Ekonomi Pertanian Fakultas Pertanian Universitas Haluoleo, 21(1), 36-44. http://dx.doi.org/10.33772/bpsosek.v37i1.7051

Satmalawati, M. E. M., \& Falo, M. (2016). Diversifikasi konsumsi pangan pokok berbasis potensi lokal dalam mewujudkan ketahanan pangan di Kecamatan Insana Barat Kabupaten Timor Tengah Utara NTT. Prosiding Semnas Hasil Penelitian Unmas Denpasar. Retrieved from https://web.archive.org/web/20170317130456id_/http://ojs.unmas.ac.id:80/index.php/pros/article/vie wFile/409/369

Sihombing, Y. (2021). Diversifikasi Pangan Lokal Untuk Mendukung Ketahanan Pangan Pada Masa Pandemi covid-19. Buletin teknologi dan informasi pertanian, 19(1), 1. Retrieved from https://bali.litbang.pertanian.go.id/wp-content/uploads/2021/07/Buletin-BPTP-Bali-Volume-19Nomor-1-April-Tahun-2021.pdf

Soekanto, S. (2017). Sosiologi Suatu Pengantar. Jakarta: Rajawali Pers.

Spradley, J. P. (2006). Metode Etnografi. Yogyakarta: PT Tiara Wacana.

Wattimena, J. A. Y., \& Hattu, V. V. (2021). Ketahanan pangan masyarakat adat sebagai wujud pemenuhan ham dalam masa pandemi covid-19. SASI, 27(2), 247-266. https://doi.org/10.47268/sasi.v27i2.448

Wulandani, B. R. D., \& Anggraini, W. (2020). Food estate sebagai ketahanan pangan di tengah pandemi covid19 di Desa Wanasaba. SELAPARANG Jurnal Pengabdian Masyarakat Berkemajuan, 4(1), 386-390. https://doi.org/10.31764/jpmb.v4i1.3062

YP, N. M. S. (2008). Diversifikasi konsumsi pangan pokok berbasis potensi lokal dalam mewujudkan ketahanan pangan rumahtangga pedesaan di Kecamatan Semin Kabupaten Gunung Kidul. Economic Journal of Emerging Markets, 13(1). https://doi.org/10.20885/vol13iss1aa50 